\title{
LOS PODERES DE RESOLUCIÓN Y CALIFICACIÓN JURÍDICA EN LA DOCTRINA JURISPRUDENCIAL DEL TRIBUNAL EUROPEO DE DERECHOS HUMANOS. PARALELISMOS CON LA SITUACIÓN CHILENA*
}

\author{
Carlos del Río Ferretti**
}

\begin{abstract}
RESUMEN
El presente estudio se destina al análisis de la doctrina emanada de la jurisprudencia del Tribunal Europeo de Derechos Humanos sobre los poderes de resolución y calificación jurídica del juez penal. El análisis abarca un arco temporal amplio: desde el caso Delcourt en 1970 hasta el caso Borisova en 2006, en los que la jurisprudencia del tribunal ha establecido ciertas formas de interpretación de las garantías del derecho a ser oído en un proceso justo y equitativo y del derecho a conocer oportunamente la acusación en relación con los poderes de enjuiciamiento. De ese desarrollo jurisprudencial, a través de su análisis jurídico procesal, se desprenden principios o criterios normativos, los cuales poseen también capacidad explicativa que se puede proyectar al caso chileno y a ciertos problemas de aplicación que se vienen registrando en la jurisprudencia nacional.
\end{abstract}

\section{ACUSACIÓN PENAL - PROCESO JUSTO - PODERES DEL JUEZ PENAL}

\author{
The resolution and legal qualification powers \\ in the doctrine settled by the European Court of \\ Human Rights: a comparison with the Chilean situation
}

\begin{abstract}
The present study focuses on the doctrine settled by European Court of Human Rights concerning the powers of resolution and legal qualification of the criminal justice judge. The analysis takes up a large timeline: starting with the Delcourt case in 1970 up to the Borisova case in 2006, where the court's opinion established certain interpretations of the right to be heard in a fair and just process and the right to know the accusation in due time. Some normative criteria or principles can be extracted from this judicial development, which have an explanatory capacity that can be also projected towards some Chilean cases.
\end{abstract}

\section{CRIMINAL ACCUSATION - DUE PROCESS - POWERS OF THE CRIMINAL JUSTICE JUDGE}

\footnotetext{
* Este estudio es resultado del proyecto Fondecyt 11075090, concedido al autor.

** Abogado, Doctor en Derecho, Profesor de Derecho procesal de la Escuela de Derecho de la Universidad Católica del Norte, Coquimbo, Chile. cdrio@ucn.cl. Artículo recibido el 29 de diciembre de 2008 y aceptado para su publicación por el Comité Editorial el 18 de mayo de 2009.
} 


\section{EXPLICACIÓN GENERAL}

bsolutamente unánime en la doctrina y en la jurisprudencia es la opinión de que
la calificación jurídica de los hechos forma parte de los poderes jurisdiccionales
del juzgador, de modo que es el juez el que determina el Derecho aplicable a los hechos que da por probados. De esta afirmación general se deriva la consecuencia de que la acusación no limita los poderes del juez respecto de este extremo, pudiendo éste apartarse de la calificación jurídica de la acusación (y también, por supuesto, de la defensa). El estudio parte de esta premisa y, no obstante la indiscutible validez de esta afirmación (general), es menester realizar una serie de matizaciones que dicen relación fundamentalmente con la manera en que el juez puede realizar su labor de calificación jurídica (enjuiciamiento jurídico de los hechos) teniendo en cuenta la acusación (y la defensa).

Hay que adelantar que en la materia ha habido una evolución importante de carácter dogmática y sobre todo jurisprudencial a partir del fortalecimiento de las garantías procesales en las últimas décadas.

Tradicionalmente se ha venido afirmando que el fundamento de la correlación entre acusación y sentencia se halla en el principio acusatorio, así, por ejemplo, lo pone de manifiesto la Exposición de Motivos LECrime ${ }^{1}$ y Aguilera de Paz, el principal comentarista de la LECrime de los primeros años del siglo $\mathrm{XX},{ }^{2}$ o actualmente Roxin. ${ }^{3}$ No cabe duda que este principio fue el configurador esencial de las reformas liberales a la justicia penal realizadas durante el siglo XIX en Europa continental, constituyéndose en el elemento definidor de un verdadero proceso penal. Desde aquella época se ha entendido que el principio acusatorio en cuanto suponía la superación del inquisitivo como sistema administrativo de imposición de pena tenía por misión esencial asegurar

\footnotetext{
${ }^{1}$ Que dice expresamente: "Para mantener al Tribunal en esta serena y elevada esfera y no desvirtuar el principio acusatorio que informa el nuevo Código, ha creído el que suscribe que únicamente al Ministerio fiscal o al acusador particular, si lo hubiere, corresponde formular el acta de acusación comprensiva de los puntos sobre que en adelante deben girar los debates, siguiendo en esto al Código de instrucción criminal austríaco, que es acaso, de los actualmente vigentes en Europa continental, el que ha desarrollado con más lógica y extensión el principio acusatorio". Y más adelante agrega: "Este principio aplicado en absoluto adolece, sin embargo, de un vicio, que han puesto de relieve insignes Magistrados encanecidos en la Administración de Justicia. Proscrita para siempre la absolución de la instancia y rigiendo sin excepción la máxima de non bis in $i d e m$, evidente es que el error del Fiscal en la calificación jurídica del hecho justiciable produce la impunidad del delincuente. Está bien que en los procesos civiles el Tribunal tenga la obligación de absolver o condenar, así como también la de ajustar estrictamente su fallo a los términos en que las partes hayan planteado el problema litigioso, o sea, la acción ejercitada por el demandante y a las excepciones formuladas por el demandado porque las cuestiones que en esos procesos se ventilan son de mero interés privado y porque además no es raro que pueda subsanarse total o parcialmente en un nuevo proceso el error padecido al entablar la acción (...) pero en los procesos criminales, que pueden incoarse de oficio, están siempre en litigio el interés social y la paz pública; y teniendo el Tribunal la obligación de condenar o absolver sin reserva alguna y sin que le sea lícito abrir un nuevo procedimiento sobre el mismo hecho ya juzgado (...)".

${ }^{2}$ Aguilera de Paz, E., Comentarios a la Ley de Enjuiciamiento Criminal, tomo V, Hijos de Reus, Madrid, 1914 , pp. 519 y ss., y en tomo VI, pp. 300 y ss.

${ }^{3}$ Roxin, C., Derecho procesal penal, Editores del Puerto, Buenos Aires, 2000 (traducción de Córdoba y Pastor), pp. 86-87.
} 
la imparcialidad del órgano decisor, mediante la obtención de la réplica artificial de la estructura tripartita del proceso civil. Es decir, se consigue un proceso penal que se realizará entre dos partes contrapuestas frente a un tercero imparcial, el juez, cuya función será decidir el litigio conforme a Derecho. De esa manera se lograba que el proceso se configurara como un actus trium personarum. ${ }^{4}$

En otras palabras, el modo en que se resuelve esta necesidad de imparcialidad es con la separación de las funciones de acusación de las de decisión - no puede ser el mismo órgano el que acuse y decida sobre la acusación-. El principio acusatorio, en consecuencia, imponía la necesidad de que un órgano ajeno al decisor de la cuestión penal introduzca aquello que va a ser objeto de la decisión, esto es, el objeto del proceso penal, para que el "juez" resuelva sobre aquél en una posición de equidistancia respecto de las partes y del objeto mismo.

Dentro de esta concepción del acusatorio, la doctrina había entendido que el objeto del proceso se estructuraba e individualizaba con base en dos criterios: uno subjetivo y el otro objetivo. El objeto del proceso se identificaba y diferenciaba de los otros posibles objetos por referencia al sujeto pasivo o imputado-acusado en contra del cual se dirige el proceso penal, ${ }^{5}$ lo que se denomina la identidad subjetiva del objeto del proceso. De otra parte, el objeto del proceso se identifica por el hecho punible (o hechos) atribuido a ese sujeto, lo que da lugar a la identidad objetiva del mismo.

El principio acusatorio entonces se resumía en la necesidad de que el órgano acusador introdujera al proceso penal el hecho punible atribuido a un sujeto, mediante la interposición de una pretensión procesal a través de la acusación. De aquí se extraía la conclusión de que la norma legal correctamente concebida debía imponer una doble limitación a la sentencia penal con referencia a la acusación. Tanto el hecho punible (o hechos sustanciales o esenciales) como el sujeto incriminado en la acusación no podían ser modificados en sentencia.

De la afirmación del párrafo anterior se deduce que la correlación entre acusación y sentencia significaba nada menos que la intangibilidad de estos dos extremos. Pero además se deduce sensu contrario que no comprendía nada más que aquello. Es decir, el restante contenido de la acusación como es la calificación jurídica de los hechos y el petitum no cabían dentro de la correlación en un sentido estricto, quedando comprendidos pura y

\footnotetext{
${ }^{4}$ Vid. entre muchos, Goldschmidt, J., Problemas jurídicos y políticos del proceso penal, Bosch, Barcelona, 1935 , pp. 23 y ss. En este trabajo, fruto de las conferencias dadas por el autor en España durante el año 1934, desarrolla una completa síntesis de su teoría sobre el proceso penal, sobre la teoría del Derecho penal como Derecho justicial material y explica la naturaleza de la acción penal o mejor dicho del derecho de acusar como derecho formal o abstracto, con el mérito de analizar en paralelo el Derecho alemán y español. Esta teoría es la que influye todo el desarrollo posterior de la teoría abstracta de la acción penal en España, vid. Montero Aroca, J., Principios del proceso penal, Tirant lo Blanch, Valencia, 1997, pp. 25-29, quien es especialmente claro en sus explicaciones en torno al principio acusatorio e inquisitivo.

${ }^{5}$ En contra De la Oliva Santos, A., Derecho procesal Penal (con Aragoneses Martínez, Hinojosa Segovia, Muerza Esparza y Tomé García), ECERA, cuarta edición, Madrid, 1999, pp. 204-205, quien estima que el objeto del proceso sólo se identifica por el hecho punible.
} 
simplemente en la esfera del poder-deber de decisión conforme a Derecho del órgano jurisdiccional. Esta fue la posición doctrinal, aunque con matices de relevancia. ${ }^{6}$

En general, para la posición clásica el principio acusatorio estaba condensado en el aforismo nemo iudex sine actore, lo cual se traducía puramente en la necesidad de que el proceso penal o juicio oral se iniciara a instancia de parte o por órgano público acusador, y éste era el principio que proyectado a la relación acusación-sentencia servía de base para justificar el deber de correlación, entendido como el deber del juez de mantenerse en su sentencia dentro del objeto del proceso introducido por el acusador. Sin embargo, no se consideraba especialmente y en toda su dimensión la función que podía cumplir el derecho de defensa y principio de contradicción en el condicionamiento de los poderes de aplicación del Derecho y del ius puniendi. Por ello el juez quedaba habilitado para calificar jurídicamente los hechos con entera libertad. Pues bien, éstas serán las cuestiones -el derecho de defensa y principio de contradicción en relación con los poderes del juez para aplicar el Derecho- las materias sobre las cuales girarán las nuevas orientaciones dogmáticas del Derecho comparado. ${ }^{7}$ Le ha correspondido en ellas una función de relieve a la jurisprudencia del TEDH, que a través de importantes fallos ha dado un impulso considerable a la eficacia y ampliación de las garantías procesales de la defensa y del principio de contradicción con relación a los poderes de resolución del juez penal.

\section{Principales líneas de aportación de la JURisprudencia del Tribunal Europeo de Derechos Humanos}

La jurisprudencia del Tribunal Europeo de Derechos Humanos (en adelante TEDH) ha tenido importancia en la configuración del principio acusatorio y de los derechos a conocer la acusación y de defensa en los modelos procesales penales europeos, en un doble sentido. Primero, indirectamente, en la medida que la jurisprudencia de los Estados europeos ha recogido la jurisprudencia del TEDH como un elemento de juicio para la interpretación de sus normas internas, buscando la armonía de su ordenamiento interno con el CEDH y la jurisprudencia del TEDH. Pero, en segundo lugar, la jurisprudencia del TEDH tiene también importancia por sí misma, directamente, porque el Tribunal tiene "jurisdicción” para conocer y fallar todas las demandas que se presenten ante él por cualquier persona física u organización no gubernamental o grupo de particulares que se consideren víctimas por alguna violación de parte de cualquiera de las Altas Partes

\footnotetext{
${ }^{6}$ Para un estudio completo del desarrollo dogmático y jurisprudencial en el Derecho europeo y en especial de la Jurisprudencia del TEDH, vid. Del Río Ferretti, C., La correlación de la sentencia con la acusación y la defensa. Estudio comparado del Derecho español con el chileno, Universidad de Valencia (Servicio de publicaciones), versión cederrón, 2007, pp. 213-244.

${ }^{7}$ Vid. un análisis general del panorama europeo en Del Río Ferretti, C., La correlación..., cit., pp. 213244. Entre nosotros también Cortez Matcovich, G., El recurso de nulidad. Doctrina y jurisprudencia, LexisNexis, segunda edición, Santiago, 2006, pp. 266 y ss.
} 
Contratantes (Estados europeos), invocando infringida alguna norma del CEDH o sus Protocolos, conforme lo dispone el Protocolo $\mathrm{N}^{\circ} 11$.

Respecto de nuestro tema, la jurisprudencia del TEDH influye de manera decisiva en el establecimiento de parámetros claros dentro de los cuales se ejerce legítimamente el poder de enjuiciamiento jurídico de los jueces puesto en relación con la vigencia del derecho a ser informado de la acusación y del principio de contradicción, cuestión que se ha logrado a través de una interpretación garantista de la necesidad de dar cabida al derecho a ser informado de la acusación de todo el contenido de la acusación, no bastando la pura introducción del hecho punible en el proceso, y dejando en lo demás operar los poderes de oficio del juzgador.

Seguidamente nos ocuparemos de las sentencias más importantes que se refieren a nuestra materia de estudio, las cuales tratan de la aplicación por parte del TEDH de los números 1 y 3 del art. 6 del $\mathrm{CEDH}$, que consagran el derecho a un proceso equitativo, especialmente el derecho a un Tribunal independiente e imparcial (art. 6.1), y el derecho a ser informado de la acusación y del derecho de defensa (art. 6.3).

Los casos que estudiaremos se han planteado por particulares que han presentado demandas en contra de los Estados europeos, invocando la infracción de las normas señaladas en las sentencias pronunciadas por los órganos jurisdiccionales de dichos Estados.

Del análisis de los casos, según se demostrará, la jurisprudencia del TEDH llega a varias conclusiones específicas, las cuales se resumen en las siguientes:

$1^{a}$. Que la infracción de los derechos de defensa y del derecho a ser informado de la acusación (art. 6.3) se incardinaría en el derecho más amplio a un juicio justo (art. 6.1) según se argumenta en el caso Pélissier y Sassi, caso Dallos y caso Borisova.

$2^{a}$. Que queda clara en la jurisprudencia la necesidad de informar de la acusación al acusado para que con ello se articule la posibilidad concreta del derecho de defensa.

$3^{a}$. Que esa necesidad de informar de la acusación alcanza no sólo a los hechos, sino que también al Derecho (caso Delcourt y caso Dallos), es decir, a la calificación jurídica. Si no se cumple con ello se concluye que la condena infringiría el art. 6.3 (caso Pélissier y Sassi y caso Borisova). La sentencia en el caso Gea Catalán, a pesar de ser desestimatoria de la infracción del art. 6.3, pues en realidad hubo un puro error mecanográfico en la cita de la norma que no produjo indefensión, también sienta la misma doctrina.

$4^{\mathrm{a}}$. Que, no obstante, este derecho a ser informado de la acusación en lo fáctico y lo jurídico no implica el desconocimiento de las facultades del órgano jurisdiccional de aplicar el Derecho, es decir, de extraer de los hechos las consecuencias jurídicas que estime más ajustadas a Derecho, con independencia de las calificaciones hechas por las partes (caso De Salvador Torres, caso Pélissier y Sassi y caso Colak).

$5^{a}$. En fin, de la jurisprudencia del TEDH se puede extraer una quinta conclusión, tal vez la más importante, que consiste en que la potestad de calificación jurídica que posee el juzgador y que lo habilita para modificar en la sentencia la calificación 
jurídica de los hechos no puede constituir la vía a través de la cual se modifique el sustrato fáctico de la sentencia (caso Colak, caso De Salvador Torres, caso Pélissier y Sassi). En otras palabras, la potestad de calificar jurídicamente los hechos no puede ser utilizada como la vía por la que se introducen subrepticiamente ampliaciones de hechos y en virtud de las cuales se justifican las mismas modificaciones de calificación jurídica. El TEDH añade, aunque no lo diga literalmente, lo que se ha denominado por la doctrina y jurisprudencia española el requisito de la homogeneidad delictiva descendente de la modificación de la calificación jurídica, entendido como aquel requisito que asegura que el cambio de calificación jurídica no se realiza en realidad sobre la base de una ampliación de los hechos de la acusación (ampliación objetiva de la acusación), que cause consecuencias agravatorias (doctrina que subyace en el caso De Salvador Torres).

En el caso Pélissier y Sassi se puso en evidencia el mismo problema señalado, pero referido a la hipótesis de autoría y complicidad: ¿puede el juez pasar de autoría a complicidad o viceversa? El TEDH dice que no, puesto que detrás del cambio de forma de participación (de calificación jurídica) se halla un hecho distinto. La modificación de la calificación constituiría una forma de introducción de un hecho distinto del contenido en la acusación, afirma la Sentencia. Lamentablemente no hace distingos ni consideraciones técnicas al respecto. Más adelante veremos cuáles habría sido menester realizar para una solución satisfactoria por lo menos a nivel de jurisdicción interna.

Esta jurisprudencia del TEDH expresada en las cinco consecuencias indicadas busca situar adecuadamente la influencia que ejerce el derecho a ser informado de la acusación y el derecho de defensa sobre los poderes del juzgador. Es así como la jurisprudencia pone de relieve el derecho a ser informado y a defenderse de todos los elementos de la acusación, tanto fácticos como jurídicos, pero, al mismo tiempo, afirma que eso no supone la anulación o desconocimiento de los poderes del juzgador de calificar jurídicamente los hechos conforme estime más ajustado a Derecho.

Debemos advertir, sin perjuicio de lo dicho precedentemente, que no podemos perder de vista dos aspectos esenciales para la cabal comprensión de lo que se explica. Primero, que la jurisprudencia del TEDH tiende a un análisis menos concreto que el de las jurisdicciones estatales, y basado por lo tanto en razonamientos más generales. Y segundo, no siempre el TEDH puede hacer consideraciones técnicas de carácter procesal, tal vez por la misma generalidad o no plena concreción de sus valoraciones jurídicas.

Por las razones expuestas, las consideraciones jurídicas del TEDH sobre la materia en estudio no resuelven todos los problemas jurídico-procesales referidos a los poderes de resolución del juez penal. Es así que, por ejemplo, no se refiere ni adhiere a un concepto técnico jurídico de hecho en sentido estricto, el cual resulta esencial para resolver coherentemente todas las situaciones referidas al correcto ejercicio de poderes de resolución. Por eso mismo en la jurisprudencia del TEDH no se encontrarán soluciones sistemáticas al problema del hecho procesal normativo que modificado da lugar a una calificación jurídica más grave. Sólo se afirma de manera general que ello en principio está prohibido, pero no se pronuncia sobre la forma de introducir esas modificaciones con el debido debate contradictorio al mismo juicio oral, o si acaso es posible que la 
introducción se realice por el mismo juez o que por lo menos ponga de relieve la situación jurídica para que a continuación el o los acusadores la asuman o la desechen (como en el sistema alemán y español). En otra parte ${ }^{8}$ hemos estudiado latamente las posibilidades de introducción de oficio por el juez o por las partes de modificaciones fácticas que supongan una agravación de la calificación jurídica, lo cual técnicamente es perfectamente admisible, pero con las debidas precisiones técnicas.

Tampoco se pronuncia sobre la necesidad de contar con una configuración única de hecho en el proceso penal (posición alemana y española) o con una configuración doble y diferenciada (como hace la doctrina italiana). A la jurisprudencia del TEDH no se le puede requerir este nivel de especificación jurídica, pues se acaba pronunciando sobre resoluciones judiciales producidas en ordenamientos jurídicos diversos que obedecen a distintas concepciones o modelos procesales.

Por los motivos expuestos es que la jurisprudencia estudiada aquí sirve en cuanto ofrece criterios generales de resolución a partir de determinadas garantías procesales generalmente reconocidas con independencia del modelo procesal concreto. Justamente a raíz de esa misma razón de generalidad jurídica en el desarrollo normativo de las garantías procesales es que tiene sentido su consideración para el sistema chileno: como dice Ferrajoli ${ }^{9}$ últimamente, las proposiciones teóricas mientras menos compromiso de intensidad respecto de un o unos ordenamientos positivos mayor extensión o amplitud explicativa poseen. Los razonamientos generales realizados por el TEDH sobre la forma de interpretar cláusulas que contienen garantías procesales universalmente reconocidas, con independencia del modelo procesal concreto, nos permiten tomar su ejemplo de justificación racional en el ámbito de que se trata. ${ }^{10}$

\section{Caso Delcourt. STEDH de 17 de enero de 1970}

Una STEDH que se cita a menudo por la doctrina, pero que sólo sirve como criterio orientador por no tratarse directamente de una cuestión de poderes de resolución, es la del caso Delcourt.

El asunto fue presentado por un ciudadano belga (Delcourt) contra el Estado de Bélgica. Planteó una cuestión sobre las posibilidades de control casacional de un fallo condenatorio dictado en su contra, y alegó la infracción de varias garantías procesales, incluida la del artículo 6.1 que se refiere al "derecho a ser oída equitativa, públicamente y dentro de un plazo razonable por un tribunal independiente e

${ }^{8}$ Del Río Ferretti, C., La correlación..., cit., passim.

${ }^{9}$ Ferrajoli, L., Principia iuris. Teoria del diritto e della democrazia, vol. I, Laterza, Bari, 2007, pp. $4-12$.

10 Al respecto Taruffo, M., Precedente e giurisprudenza, Editoriale Scientifica, 2007, pp. 31-36, que analiza la progresiva utilización del precedente como ejemplo, producido en un ordenamiento supranacional o extranjero avanzado, y cuya fuerza jurídica se basa en su capacidad persuasoria, cuando en él se hace aplicación de principios jurídicos compartidos universalmente o al menos por una familia jurídica. 
imparcial, establecido por la Ley, que decidirá (...) sobre el fundamento de cualquier acusación en materia penal dirigida contra ella”.

Resulta ser este el primer pronunciamiento relevante del TEDH. En él establece, si bien incidentalmente, que la fundamentación y determinación de la acusación no sólo se refería a los hechos sino también al Derecho, en cuanto ambos elementos debían ser sometidos a debate contradictorio. ${ }^{11}$

La doctrina ha interpretado las alusiones que hace esta sentencia a la fundamentación fáctica y jurídica de las resoluciones judiciales y al control jurisdiccional mediante casación, en el sentido de que el sujeto pasivo tiene derecho a conocer y contradecir en esos dos aspectos la acusación (estimada en la sentencia condenatoria), de manera que si no se dan estas garantías habría infracción a la disposición del artículo 6.1 ${ }^{12}$. Es decir, del derecho a un proceso justo.

\section{Caso Colak. STEDH de 6 de diciembre de 1988 (Núm. 0180/1988) (13 $^{13}$}

Esta sentencia también es de aquellas que se cita frecuentemente, aunque sólo sirva parcialmente para nuestro tema, porque el problema que se plantea es una cuestión más bien referida al funcionamiento y dinámica de un juicio, y las consideraciones en virtud de las cuales se decide la cuestión planteada son más bien de sentido común, que no de técnica procesal. En todo caso, tanto el problema como la solución, ambas referidas a la acusación y al derecho a un juicio justo, nos obligan a comentarla.

En resumen, el caso es el siguiente: ${ }^{14}$

Serif Colak era un ciudadano turco que residía y trabajaba en la ex República Federal de Alemania. En una pelea (1979) hirió de una cuchillada en el vientre

${ }^{11}$ STEDH de 17 de enero de 1970 (caso Delcourt), en su fundamentación expresa: "Más aún, la expresión "bien-fondé", que se halla en el texto francés del artículo 6.1, se refiere no sólo a que la acusación esté bien fundada en los hechos, sino a que lo sea en derecho. Por ello, el control de validez que asume el Tribunal de Casación podría llevar a sostener que los Tribunales inferiores, cuando examinan los hechos sobre los que se fundamenta la imputación, han actuado violando bien el derecho penal, bien las formas procesales que tienen una naturaleza esencial o vician de nulidad al fallo (...) al menos en el primero de dichos supuestos la acusación se muestra sin duda alguna infundada (...)".

"Por otra parte, el Tribunal hace notar que, de hecho el texto inglés del artículo 6 no contiene expresión alguna equivalente a "bien-fondé"; se usa, por el contrario, la expresión mucho más amplia de "determination of any criminal charge". Por ello, una acusación penal no está en realidad "determinada" mientras la decisión de libertad o condena no llega a su fin. El procedimiento penal forma y debe, normalmente, llegar a una decisión firme".

12 Ortells Ramos, M., "Principio acusatorio, poderes oficiales del juzgador y principio de contradicción. Una crítica del cambio jurisprudencial sobre correlación entre acusación y sentencia”, en Justicia, IV, 1991, p. 777.

${ }^{13}$ STEDH de 6 de diciembre de 1988 (Núm. 0180/1988). Base de datos El Derecho 1988/10492.

${ }^{14}$ El resumen se hace a partir del que aparece en la base de datos española de El Derecho y de la sentencia en la versión original inglesa que se publica ahí mismo. 
a otro ciudadano turco, hecho por el cual fue detenido y acusado de tentativa de homicidio. El juicio oral comenzó a desarrollarse el 28 de abril de 1980. El 5 de mayo el señor Colak y su defensa fueron advertidos de la posibilidad de que se dictara condena por lesiones y heridas graves. Suspendidas las sesiones el 13 de mayo al no comparecer la víctima, el señor Colak fue puesto en libertad bajo fianza. La vista oral se reanudó en enero de 1981. En el transcurso de una de las sesiones el Tribunal le informó a la defensa la posibilidad de que el señor Colak fuera condenado únicamente por lesiones y heridas graves (ya le había informado antes de lo mismo). El Ministerio Fiscal modificó su calificación de los hechos al final de la sesión del 23 de enero, solicitando que el acusado fuera condenado por lesiones y heridas graves. Con todo, en la sesión de 10 de febrero de 1981, el Tribunal consideró al señor Colak culpable de tentativa de homicidio y le condenó a cinco años de prisión.

El abogado de la defensa sostuvo que el Presidente del Tribunal, fuera de la sala de audiencia, le aseguró que el Tribunal consideraría sólo las posibles lesiones y heridas graves, y que cualquier cambio al respecto le sería oportunamente comunicado; tal extremo fue posteriormente negado ante el Tribunal Federal de Justicia por el referido Presidente.

El caso tiene interés para nuestro modelo pues se basa en una aplicación de una norma equivalente a la del art. 341 inciso $2^{\circ} \mathrm{CPP}$, que contempla la tesis del tribunal, que en la StPO se halla en el parágrafo 265, el cual señala que el tribunal debe advertir a las partes de una posible modificación de calificación jurídica, con el fin de facilitar el debate con nueva prueba. ${ }^{15}$ Se somete el asunto al TEDH, alegando el acusado la violación del artículo 6.1 del CEDH al haber sido inducido por el Presidente del Tribunal a realizar la defensa de la calificación de lesiones y heridas graves y descuidar la de homicidio tentado.

El TEDH desestima estos argumentos porque considera que es imposible probar la existencia de la mencionada conversación supuestamente acaecida fuera de la sala de audiencia entre el abogado del señor Colak y el Presidente de la Sala de lo Criminal y, aunque se hubiera producido, no vinculaba en modo alguno a los demás Magistrados. Lo único que vincula a los jueces de un tribunal son las actuaciones que se desarrollan en la audiencia, lo cual hace suponer al TEDH que era conocido por la defensa que se podía condenar por la calificación de homicidio tentado, que era lo que pedía la acusación inicialmente. De otra parte, el TEDH considera que el abogado del señor Colak debió haber solicitado la correspondiente confirmación oficial asegurándose de ese modo que las apreciaciones del Presidente reflejaban las de toda la Sala.

${ }^{15}$ Vid. Roxin, C., Derecho procesal penal, cit., p. 362; Gómez Colomer, J. L., El proceso penal alemán. Introducción y normas básicas, Bosch, Barcelona, 1985, pp. 39-42 y 366-367; Del Río Ferretti, C., La correlación..., cit., p. 563. 
Por lo dicho, el TEDH concluye por unanimidad que no se produjo violación alguna del art. 6.1 del Convenio. ${ }^{16}$

Nuevamente está presente aquí el asunto de la merma de las posibilidades defensivas, invocándola en este caso dentro de la garantía del juicio justo como elemento que se esgrime para medir las facultades de decisión del órgano jurisdiccional. De la resolución citada se concluye que las facultades de calificación jurídica del órgano jurisdiccional permanecen intactas siempre que se mantenga dentro de los hechos. ${ }^{17}$ También se puede deducir que la tesis puede ser propuesta sin problemas por el juez o tribunal, pudiendo ser distintas de la del acusador, y que no necesita ser acogida por ninguna de las partes para poder condenar por ella. ${ }^{18}$

\section{Caso Gea Catalán. STEDH de 10 de febrero de 1995 (BDA, m. TEDH 1995/1)}

El caso se refiere al artículo 6.3 (letra a) que consagra el derecho del acusado "a ser informado (...) detalladamente, de la naturaleza y de la causa de la acusación formulada contra él”.

El señor Francisco Gea Catalán, en los primeros meses de 1985, aprovechando su condición de empleado del Banco de Fomento, hizo descontar en su favor unas letras de cambio que había librado él mismo a cargo de personas inexistentes.

En sus conclusiones provisionales, el MF calificó los hechos como delito de estafa castigado por el artículo 528 con la circunstancia agravante muy cualificada prevista en el apartado 1 del artículo 529 del Código Penal.

El Banco, como acusación particular, formuló sus conclusiones que, en lo esencial, coincidían con las del MF.

Por sentencia de 22 enero de 1988, la AP condenó a Gea Catalán, entre otras, a una pena de dos años y cuatro meses de prisión por estafa, la cual se elevaba a 5.610.150 pesetas, basando la condena en el apartado 7 del artículo 529 del Código Penal, estimando que existía una agravante muy cualificada.

El señor Gea Catalán recurrió en casación invocando el artículo 24.2 de la CE, en la cual se quejaba de que se le había aplicado la circunstancia agravante del apartado 7 del artículo 529 sin haber sido informado previamente. A este respecto, señalaba que tanto el MF como la acusación particular se habían referido en sus conclusiones únicamente al apartado 1 de dicho artículo, discordancia que había conculcado su derecho de defensa.

El TS desestimó el recurso argumentando que la discordancia denunciada por el señor Gea Catalán provenía simplemente de un error material, fácil de comprender y corregir empleando las reglas de la lógica y del sentido común, ya que habría sido absurdo aplicar a los hechos en cuestión el apartado 1 del artículo 529.

\footnotetext{
${ }^{16}$ Vid. STEDH de 6 de diciembre de 1988 (Núm. 0180/1988).

17 Ortells Ramos, M., "Principio acusatorio...", cit, p. 778.

18 En términos parecidos Ortells Ramos, M., "Principio acusatorio...", cit., p. 778.
} 
El recurrente interpuso ante el TC un recurso de amparo alegando la violación de su derecho de defensa. Dicho recurso fue desestimado por carencia de contenido constitucional, al considerar el TC que solamente había ocurrido una inversión dactilográfica consistente en hacer referencia al apartado 1 del artículo 529 en lugar del apartado 7, lo cual no modificaba ni el motivo de acusación ni los hechos incriminados, de manera que el error material que se había producido no tenía ninguna incidencia sobre su derecho de defensa.

Plantea el acusado una demanda ante el TEDH, invocando la infracción del art. 6.3, letra (a) del CEDH, es decir, del derecho a ser informado detalladamente de la naturaleza de la causa de la acusación formulada contra él; derecho que implicaba conocer los hechos y todas las calificaciones jurídicas de los mismos.

El TEDH desestima la demanda por falta de fundamento de la misma, ya que en su opinión la demanda se basa en un puro error de cita de la norma que se pretende aplicar, pero del contexto del juicio se puede apreciar que dicho dislate en nada afectó el derecho de defensa.

No obstante la desestimación de la demanda del ciudadano español Gea Catalán, sobre la supuesta infracción a las garantías del artículo 6.3, queda clara la importancia de la doctrina que emana de dicha disposición en el sentido de configurar un verdadero derecho a ser informado de la acusación. En este caso no se estima la demanda porque justamente se entiende respetado el derecho a ser informado de la acusación, en el sentido de que un simple error mecanográfico al citar la norma aplicada para calificar el ilícito como aconteció en este caso no es suficiente para justificar la infracción que se reclamó, cuando está claro que el acusado estaba en pleno conocimiento de lo que se le acusaba o debía estarlo con un razonamiento deductivo mínimo. ${ }^{19}$

${ }^{19}$ STEDH de 10 de febrero de 1995 (BDA, m. TEDH 1995\1): “25. El señor Gea Catalán alega la violación del artículo 6.3 , a) del Convenio, redactado como sigue:

"(...) Todo acusado tiene, como mínimo, los siguientes derechos:”

“a) a ser informado, en el más breve plazo (...) y detalladamente, de la naturaleza y de la causa de la acusación formulada contra él (...)”.

"Esta se derivaría de que su condena se basaba en el apartado 7 del artículo 529 del Código Penal, y no en su apartado 1, invocado por el Ministerio Fiscal y la acusación particular (...)”.

“28. El Tribunal considera, al igual que el Gobierno, que la discordancia denunciada era el resultado, con toda evidencia, de un simple error material, cometido al mecanografiar las conclusiones del Ministerio Fiscal y reproducidas posteriormente, en diversas ocasiones, por éste y por la acusación particular (apartados 10 y 11 supra). Así lo comprendieron, además, el Tribunal Supremo y el Tribunal Constitucional al rechazar el recurso de casación y el recurso de amparo del demandante (apartados 13-14 supra)".

“29. Vista la claridad de la calificación jurídica de los hechos probados expuestos en el Auto de remisión del Juez de Instrucción de 1 julio 1986 (apartado 9 supra), el Tribunal no ve cómo el señor Gea Catalán podría invocar una falta de información sobre todos los elementos de la acusación, ya que las conclusiones de las partes acusadoras se basaban en los mismos datos (apartado 10 supra). Además, la aplicación en el caso de autos del apartado 1 del artículo 529 del Código Penal habría sido absurdo, como justamente lo señala el Tribunal Supremo (apartado 14 supra), mientras que la del apartado 7, aunque no fuese de aplicación imperativa, al menos se deducía de un razonamiento deductivo mínimo”. 
4. Caso De Salvador Torres. STEDH de 24 de octubre de 1996 (BDA, m. TEDH 1996/1)

En este asunto se alega la infracción del art. 6.3 CEDH, concretamente, la violación del derecho a ser informado de la acusación, causada por la modificación en sentencia de la calificación jurídica del hecho punible.

De Salvador Torres, el demandante ante el TEDH, era director administrativo de un hospital público de Barcelona, cuando concertó con un banco el depósito de fondos a cambio del pago de intereses superiores al tipo legal.

La diferencia entre los tipos legales y los extratipos pagados por el banco sobre las cantidades depositadas eran ingresadas a la cuenta personal del señor De Salvador Torres.

Entre 1966 y 1983 se transfirió de esta manera al interesado un importe total de 147.614 .565 pesetas.

El MF y el acusador particular acusaron por el delito de malversación de caudales públicos.

La AP declaró que el señor De Salvador Torres pertenecía a la categoría de encargado de fondos públicos, pero que las sumas de las cuales se había apropiado no eran "caudales públicos” y que, por lo tanto, el artículo 394.4 no era de aplicación al caso. Señaló que, contemplada su posición en el hospital, el interesado no tenía la calidad de funcionario strictu sensu, por lo que descartó las acusaciones de corrupción. El señor De Salvador Torres fue, no obstante, condenado como culpable del delito de apropiación indebida, delito castigado por el artículo 535 y condenado a dieciocho meses de reclusión en virtud de los artículos 528 y 529.7 del Código Penal.

El MF y el acusador particular (el Hospital, según textualmente se menciona en la sentencia) recurrieron de casación. Calificaron como caudales públicos las sumas en litigio y solicitaron nuevamente la condena del demandante por el delito de malversación de caudales públicos, previsto en los artículos 394.4 y 399 del CPe. En sus conclusiones, el MF insistió en el hecho de que la AP había claramente reconocido que el acusado tenía a su cargo fondos pertenecientes a un establecimiento público de acuerdo con el artículo 399.

El TS revocó la sentencia recurrida y declaró al señor De Salvador Torres culpable del delito de apropiación indebida por la que había sido condenado, pero con la circunstancia agravante de haberse prevalido, en el ejercicio de su cargo, del carácter público de su función (artículo 10.10 del Código Penal). El Tribunal estimó que la aplicación de esta circunstancia agravante derivaba implícitamente de las peticiones del MF.

Haciendo uso de sus facultades, el TS condenó al demandante a cinco años de reclusión, duración máxima para el delito de apropiación indebida prevista en las normas de fijación de penas establecida en el artículo 61.2 del CPe.

De Salvador Torres interpuso ante el TC un recurso de amparo. Alegó no haber sido informado de todos los elementos de hecho que componen la acusación contra 
él formulada, lo que habría violado su derecho a un juicio justo (art. 24 de la CE). Dicho recurso fue inadmitido.

El acusado presenta demanda ante el TEDH, invocando la infracción del art. 6.3 del CEDH.

El TEDH estima que no se produjo vulneración del artículo 6.3 del CEDH, esencialmente porque valora que no hubo ninguna indefensión al considerar que el acusado estuvo perfectamente informado. Dice la STEDH "hay que considerar que el señor De Salvador Torres era consciente de que, cuando se tratara de fijar la pena, el Juez -es decir, la Audiencia Provincial y el Tribunal Supremo- podría, en el contexto de una apropiación indebida, ver que en este elemento factual subyace una circunstancia agravante".

Lo anterior es lógico si se considera que la calificación acusadora era de malversación de caudales públicos, lo que suponía la calidad de públicos de los fondos y de funcionario público del autor, de modo que la circunstancia fáctica había sido introducida por la propia parte acusadora, e incluso su calificación jurídica, en un sentido amplio. Lo que ocurre es que la circunstancia en vez de ser calificada como circunstancia que da lugar a un delito funcionarial (delito especial impropio), como proponía la acusación (circunstancia calificante que daba origen al delito funcionarial de malversación), es valorada por el juzgador como circunstancia agravante del tipo común de "apropiación indebida", con lo cual lo que hace el juzgador es descomponer la calificación jurídica de la acusación de delito especial impropio (malversación) en un tipo penal común con una agravante genérica, de modo que contempla los mismos elementos fáctico-jurídicos de la acusación, pero bajo una calificación jurídica distinta: que separa en un tipo penal común más una agravante genérica. Por otra parte, el delito por el que se condena, aun con la agravante, es de menor entidad que el de la acusación y fue sancionado con pena menor. ${ }^{20}$

Como concluye la STEDH, no hubo merma de las posibilidades de defensa, porque la circunstancia que da lugar a la apreciación de agravante, es decir, la calidad de funcionario público, se encontraba presente en la misma acusación por malversación de caudales públicos que se dirigía en contra del acusado en calidad de Director administrativo de un hospital público, de modo que al calificar por un tipo común como la apropiación indebida, que tiene asignada pena más leve, estimando la calidad de funcionario como una circunstancia agravante del delito de apropiación indebida, el juzgador no hace más que calificar una circunstancia que estaba contenida en el sustrato de la acusación por malversación de fondos públicos. ${ }^{21}$

${ }^{20}$ En nuestro medio vid. Rodríguez Collao, L. y Ossandón Widow, M., Delitos contra la función pública. El Derecho penal frente a la corrupción política, administrativa y judicial, Editorial Jurídica de Chile, Santiago, 2005, pp. 126-130.

${ }^{21}$ STEDH de 24 de octubre de 1996 (BDA, m. TEDH 1996\1): “30. El Tribunal señala que, desde el principio, el Juez de instrucción estimó que los hechos, tal como él los había establecido, pertenecían a la categoría de delito de malversación de caudales públicos (apartado 8 supra). El Ministerio Fiscal y el Hospital, acusación particular, aceptaron ambos esta calificación jurídica y la mantuvieron a lo largo del procedimiento (apartados 8 y 10 supra). Ahora bien, en Derecho Español, el delito de malversación de 
Se halla latente en esta sentencia del TEDH el concepto de homogeneidad delictiva descendente como argumento que legitima la modificación de la calificación jurídica, en el sentido de que la modificación de la calificación jurídica en la sentencia se produjo sobre la base de los mismos elementos fáctico-jurídicos en que se apoyaba la acusación, sin añadir nuevos elementos que pudieran producir indefensión.

Éstas son las razones por las que el TEDH no aprecia ninguna infracción al art. 6.3 del $\mathrm{CEDH}$, concordando con la doctrina que ha venido sustentando la jurisprudencia española (TS y TC) de la homogeneidad delictiva descendente.

\section{Caso Pélissier y Sassi. STEDH de 25 de marzo de 1999 (BDA, m. TEDH 1999\10)}

Se alega en este caso la infracción de los números 1 y 3 del art. 6 CEDH, fundamentalmente por no haber sido informado el acusado de todos los elementos de la acusación, privándosele de su derecho de defensa y a contradecir en todos los términos la acusación, a raíz de un cambio de calificación jurídica en sentencia, en virtud del cual se modificó la forma de participación sostenida en la acusación.

caudales públicos exige que el autor sea un funcionario o un administrador de fondos al cometer el delito y que las sumas malversadas sean "fondos públicos" (apartados 15 y 16 supra)".

“31. El Tribunal constata además que el demandante nunca ha rebatido que por su condición de director administrativo de un hospital público de Barcelona, pertenecía a la categoría de personas "encargadas” (...) de fondos pertenecientes a provincias o municipios, a establecimientos de instrucción o de beneficencia”, o a la de administradores o depositarios de fondos colocados por una autoridad pública (artículo 399 del Código Penal -apartado 16 supra-)".

"El sumario muestra que las partes estaban de acuerdo en este punto (apartados 9 y 11 supra)".

"Dada su condición, el señor De Salvador Torres ocupaba un cargo de carácter público".

"Ahora bien, ni la Audiencia Provincial ni el Tribunal Supremo han calificado las cantidades sustraídas de "fondos públicos". Estos dos órganos han aplicado el delito más general de apropiación indebida. Sin embargo, mientras que la Audiencia Provincial señalaba que ninguna circunstancia agravante de carácter general era de aplicación en este caso (apartado 9 supra), el Tribunal Supremo ha considerado que el hecho -establecido por la Audiencia Provincial y no rebatido por el demandante- de que el señor De Salvador Torres se hubiera prevalido de su condición de director administrativo de un establecimiento público, agravaba el delito. En el ejercicio de sus facultades (apartados 22 y 23 supra), el Tribunal Supremo ha condenado a una pena que siendo mayor que la pronunciada por la Audiencia Provincial, era muy inferior a la requerida por la acusación al principio y a lo largo del procedimiento (apartados 8 y 10 supra)”.

“32. El Tribunal subraya que, contrariamente a los artículos 394 y 399 del Código Penal, el artículo 10.10 exige únicamente que el autor del delito se haya prevalido del "carácter público de su función”. Es evidente que al constatar la existencia de una circunstancia agravante, el Tribunal Supremo falle en función de este elemento del tipo (ver apartado 12, supra y mutatis mutandis, la Sentencia Gea Catalán contra España de 10 febrero 1995 (BDA, m. TEDH 1995\1), serie A núm. 309, pg. 11, ap. 29)”.

“33. En resumen, como ha dicho el Tribunal Constitucional en su Auto de 20 julio 1992 (apartado 13 supra), el carácter público de las funciones ejercidas por el demandante era un elemento inherente de la acusación inicial de malversación de caudales públicos que el demandante conocía, pues, desde el comienzo del procedimiento. Por lo tanto, hay que considerar que el señor De Salvador Torres era consciente de que, cuando se tratara de fijar la pena, el Juez - es decir, la Audiencia Provincial y el Tribunal Supremo- podrían, en el contexto de una apropiación indebida, ver que en este elemento factual subyace una circunstancia agravante". 
Fernand Cortez era gerente y socio de la sociedad Bleu Marine, compañía que se dedicaba a la construcción de barcos. Paralelamente había constituido una sociedad inmobiliaria con Pélissier y Sassi con el fin de adquirir un inmueble para alquilárselo a Bleu Marine. Pero, por problemas de administración e insolvencia se produce la cesación de pagos de la primera compañía. Cortez, junto con Pélissier y Sassi, fue sometido a juicio como autor de falsedad de escritura mercantil y estafa, y luego por estafa simple y fraudulenta y por abuso de confianza. También en el procedimiento de instrucción uno de los acusadores había solicitado tener como posibles cómplices en la quiebra a Pélissier y Sassi.

En primera instancia Cortez fue condenado y Pélissier y Sassi absueltos.

La sentencia fue apelada por el MP y Cortez, solicitando una calificación subsidiaria a la que se había pedido en la instancia. El Tribunal de apelación hizo una nueva calificación y condenó a los acusados absueltos en instancia como cómplices en el delito de quiebra.

Pélissier y Sassi recurrieron de casación la sentencia por supuesta infracción del derecho de defensa al no haberse producido debate contradictorio sobre la nueva calificación. El recurso se desestimó por el Tribunal de casación porque consideró que los Tribunales de primera y segunda instancia caracterizaron completamente los hechos, materiales e intencionales, tanto del delito principal de quiebra como el de complicidad, de modo que lo que se cuestiona en el recurso es la facultad soberana de aplicar el Derecho a los hechos y circunstancias contradictoriamente debatidos.

Se presentó demanda por Pélissier y Sassi ante el TEDH, fundada en la infracción de los números 1 y 3 letra (a) y (b) del art. 6 del CEDH.

La sentencia $^{22}$ del TEDH que resuelve el caso contiene varios aportes al tema de este trabajo. No obstante, en lo que nos interesa en este acápite, cabe señalar lo referido

${ }^{22}$ STEDH de 25 de marzo de 1999 (BDA, m. TEDH 1999\10), señala en lo pertinente: "51. El Tribunal recuerda que las disposiciones del apartado 3 a) del artículo 6 muestran la necesidad de poner un cuidado extremo en notificar "la acusación" al interesado. El acta de acusación juega un papel determinante en las diligencias penales: a partir de su notificación, la persona encausada está oficialmente informada por escrito de la base jurídica y de hecho de las imputaciones que se formulan contra ella (Sentencia Kamasinski contra Austria de 19 diciembre 1989, serie A núm. 168, pgs. 36-37, ap. 79). El artículo 6.3 a) del Convenio reconoce al acusado el derecho a ser informado no sólo del motivo de la acusación, es decir, de los hechos materiales de los que se le acusa y sobre los que se basa la acusación, sino también de la calificación jurídica dada a estos hechos y esto, como indica justamente la Comisión, de manera detallada".

"55. El Tribunal señala, en primer lugar, que en la providencia de remisión ante el Tribunal correccional de 27 de junio de 1990, únicamente se imputaba a los demandantes el delito de quiebra (apartado 26 "supra”). Aunque la acusación adicional de los días 4 y 6 de diciembre de 1986 hubiera contemplado, a fin de cuentas sin motivación particular, los textos relativos tanto a la quiebra como a la complicidad en la quiebra (apartado 22 "supra”), el Tribunal constata que la información facilitada por el Juez de instrucción se refería únicamente a los hechos de quiebra. Nada hay que permita pensar que la posibilidad de una complicidad en la quiebra, mencionada en un escrito dirigido al Juez de instrucción por el abogado de la sociedad Chantiers Beneteau (apartado 21 "supra”), haya sido realmente tenida en cuenta en el curso de la instrucción”. 
a la interpretación que hace de los artículos 6.1 y 6.3 del Convenio con relación a las facultades de calificación jurídica del tribunal. A este respecto quedan nítidamente expuestas estas cuestiones:

$1^{a}$. Establece el irrebatible "derecho" de los tribunales a dar la calificación jurídica a los hechos que le han sometido a su conocimiento y resolución.

$2^{a}$. En opinión del TEDH, sin embargo, la complicidad no puede ser considerada como una simple forma de participación en el delito principal, cuando el CP francés distinguía claramente una de otra.

$3^{\mathrm{a}}$. Tampoco la complicidad podía ser considerada, en el caso concreto, como elemento intrínseco de la acusación que los acusados hubieran conocido desde el principio, porque si bien durante la instrucción, en un escrito de parte, se mencionó la posibilidad de que los imputados pudieran haber incurrido en complicidad en la quiebra, eso no se concretó en una acusación, de modo que no se satisface la exigencia de que exista acusación explícita del delito concreto. Además el TEDH estima que de los antecedentes de los debates se puede colegir que no hubo ningún planteamiento sobre la cuestión. Por otra parte, el TEDH considera que

"Ante el Tribunal correccional, los debates se centraron únicamente sobre el delito de quiebra (apartado 28 "supra”). Los términos de la sentencia dictada por el Tribunal confirman la ausencia de la noción de "complicidad" en los debates judiciales ("ibidem”)".

"Las autoridades judiciales no acusaron en ningún momento a los demandantes, al ser enviado el asunto ante el Tribunal de apelación de Aix-en-Provence tras el recurso interpuesto por el Ministerio Fiscal, de una eventual complicidad en la quiebra, ni en la citación para comparecer ni en el transcurso de los debates (apartado 30 "supra”) (...)".

"56. El Tribunal considera, a la vista de estos elementos, que no se ha probado que los demandantes hubieran tenido conocimiento de la posibilidad de nueva calificación de los hechos en "complicidad en la quiebra” por el Tribunal de apelación (...)”.

“58. (...) Ciertamente, la complicidad remite, por naturaleza, a un delito principal, el cometido por el autor del delito. Los actos de los cómplices sólo adquieren carácter penal por referencia al delito cometido por este autor, lo que expresa la noción de "préstamo de criminalidad". Pero, además de este primer elemento constitutivo, la complicidad requiere igualmente la presencia de un elemento material, es decir, la comisión de un acto específico como lo prevé el antiguo artículo 60 del Código Penal, y un elemento intencional, esto es la consciencia de la ayuda aportada a la comisión del delito (apartado 36 "supra")".

"59. El Tribunal no comparte la opinión del Gobierno cuando mantiene que la complicidad sólo constituye un simple grado de participación en el delito principal. El Código Penal lo establecía de manera diferente en la época de los hechos y los artículos 402 y 403 distinguían claramente cómplice y autor, debiendo este último tener una de las cualidades contempladas en el artículo 196 de la Ley de 25 de enero de 1985 y recordadas por el antiguo artículo 403 del Código Penal (apartados 36-37 "supra”)".

"60. El Tribunal no debe valorar la procedencia de los motivos de defensa que los demandantes hubieran podido invocar si hubieran tenido la posibilidad de debatir la complicidad en la quiebra. Señala simplemente que es plausible sostener que estos motivos habrían sido diferentes de los elegidos a fin de rebatir la acción principal. Acusados de complicidad, los señores Pélissier y Sassi habrían tenido que convencer a sus Jueces por un lado, de que no habían cometido ninguno de los actos de complicidad previstos por la Ley y, por otro lado, de que si se les reprochaban actos específicos de complicidad, no habían sido conscientes de ayudar a la comisión del delito (...)".

“61. Teniendo en cuenta lo que antecede, el Tribunal considera igualmente que la complicidad no constituía un elemento intrínseco de la acusación que los acusados hubieran conocido desde el inicio del procedimiento (...)". 
la complicidad, aunque sea forma de participación en un delito principal y su existencia y relevancia dependa de él, importa un hecho distinto y diferenciado del hecho delictivo principal, con sus propios requisitos objetivos y subjetivos, de modo que detrás del cambio de calificación jurídica también existe un cambio fáctico.

$4^{\mathrm{a}}$. El TEDH opina que el artículo 6.3 asegura el derecho a ser informado de la acusación, derecho que resulta esencial para poder articular una defensa eficaz, lo cual se incardina dentro del proceso justo del artículo 6.1. Y lo más importante, declara que este derecho a ser informado de la acusación no sólo alcanza a los hechos que se le someten al tribunal, sino también a las cuestiones y calificaciones jurídicas implicadas.

$5^{a}$. Concluye que en el caso concreto no se acredita que se haya informado a los condenados de la posibilidad de la nueva calificación de complicidad, detrás de la cual hay un hecho diverso del originalmente imputado en acusación, ni tampoco queda claro que se haya debatido la posibilidad de calificar los hechos como complicidad.

6a. El TEDH declara que era plausible sostener que los imputados, en caso de haber conocido la posibilidad de calificación de complicidad en la quiebra, podrían haber articulado una defensa distinta a la que hicieron.

Como consecuencia de estas consideraciones, el TEDH estima que hubo violación del artículo 6.3.

\section{Caso Dallos. STEDH de 1 de marzo de 2001 (BDA, m. TEDH 2001\197)}

Se alega por el acusado las infracciones de los números 1 y 3 del art. 6 CEDH, al ser privado de su derecho a ser oído por tribunal imparcial y del derecho a ser informado de la acusación y de defensa, producida por un cambio de calificación jurídica.

Dallos fue condenado en primera instancia por un delito de malversación con agravantes. Éste dedujo recurso de apelación en contra de la sentencia, pidiendo su absolución. No obstante, el tribunal de apelación (tribunal regional) confirmó la sentencia condenatoria, pero modificó la calificación de los hechos, estimando que no constituían malversación con agravante, sino que fraude con agravante. A continuación, el condenado y su abogado presentaron una petición de revisión ante el TS de Hungría. La defensa mantenía que había sido condenado por error y que la recalificación de los hechos de la acusación constituía infracción a las garantías procesales. Sin embargo, el TS de Hungría desestimó la revisión y confirmó la sentencia condenatoria.

Agotada la vía interna, el acusado demandó al Estado húngaro ante el TEDH, invocando la infracción del art. 6.1 del CEDH, sobre el derecho a ser oído equitativamente por un tribunal independiente e imparcial, y del art. 6.3 (a) y (b) del CEDH, referido al derecho a ser informado de la acusación y a disponer de tiempo y facilidades 
para preparar la defensa. Estas infracciones a las normas invocadas se habrían producido, según Dallos, por la condena en segunda instancia por delito distinto del que había sido condenado en primera instancia, de modo que tal recalificación en apelación le "impidió ejercer su derecho de defensa adecuadamente y, por dicha razón, los procesos seguidos contra él habían devenido injustos". ${ }^{23}$

Ante esta demanda el TEDH resuelve que la condena en segunda instancia que recalificó los hechos supuso un menoscabo al derecho a ser informado de la acusación, ya que no se le notificó la posibilidad de recalificación de los hechos, estableciendo que el derecho a ser informado de la acusación no sólo exige el conocimiento del "motivo de la acusación, es decir, de los hechos materiales de los que se le acusa, sino también de la calificación jurídica dada a estos hechos". ${ }^{24}$ No obstante haber realizado dicha constatación, el TEDH desestima la demanda de Dallos porque considera que la petición de revisión ante el TS de Hungría permitió una revisión completa de la cuestión debatida, con lo cual estima satisfecha la posibilidad de defensa (a posteriori) respecto a esa recalificación que realizó el tribunal de apelación. ${ }^{25}$

${ }^{23}$ STEDH de 1 de marzo de 2001 (BDA, m. TEDH 2001\197).

${ }^{24}$ STEDH de 1 de marzo de 2001 (BDA, m. TEDH 2001\197).

${ }^{25}$ La STEDH de 1 de marzo de 2001 (BDA, m. TEDH 2001\197), en lo pertinente señala: "Decisión del Tribunal. 47. (...) Las disposiciones del apartado 3 a) del artículo 6 muestran la necesidad de poner un cuidado extremo en la notificación de la "acusación" al demandado. El acta de acusación juega un papel decisivo en un proceso penal, ya que a partir de ese momento, la persona encausada está oficialmente informada por escrito de la base jurídica y de hecho de las imputaciones que se formulan contra ella (...) El art. 6.3 a) del Convenio reconoce al acusado el derecho a ser informado no sólo del "motivo" de la acusación, es decir, de los hechos materiales de los que se le acusa, sino también de la calificación jurídica dada a estos hechos y esto de manera detallada (...)".

"El alcance de dichas disposiciones debe apreciarse en especial a la luz del derecho más amplio a un juicio justo, derecho este garantizado por el artículo 6.1 del Convenio (...)”.

“48. En el asunto que nos ocupa, el Tribunal señala que el demandante no fue avisado de que el Tribunal Regional podía dar una nueva calificación jurídica a su delito como fraude. Esta circunstancia, sin duda alguna, afectó negativamente a sus posibilidades de defensa frente a unos cargos por los que finalmente fue condenado".

“49. Sin embargo, a diferencia de la Comisión, el Tribunal atribuye una importancia decisiva a los procesos seguidos ante el Tribunal Supremo”.

“50. Debe señalarse que el Tribunal Supremo revisó el caso del demandante por completo, tanto desde el punto de vista procesal como del punto de vista de la ley. Además de haber estudiado los expedientes de los Tribunales inferiores, y las alegaciones del demandante y del fiscal, los magistrados que llevaron a cabo la revisión escucharon, en vista pública, los alegatos orales de la defensa del demandante y de la Fiscalía General (apartado 15 “supra”). Es más, el propio Tribunal Supremo pudo haber reemplazado la condena del demandante, bajo el artículo 291.3 de la Ley de Enjuiciamiento Criminal (apartado 30 "supra”), por una absolución".

"51. El Tribunal señala que el Tribunal Supremo rechazó la petición de absolución por el cargo de fraude, realizada por la defensa del demandante (...)”.

"Estas circunstancias llevan al Tribunal a estimar que el propio Tribunal Supremo examinó si el demandante era culpable o no de un delito de fraude".

"52. Por tanto, y aceptando el argumento del Gobierno en este punto, el Tribunal considera que el demandante disfrutó de la oportunidad de presentar ante el Tribunal Supremo los argumentos de su defensa en relación a la nueva calificación jurídica del delito como fraude. Tras comprobar la equidad del proceso en 


\section{Caso Borisova. STEDH de 21 de diciembre de 2006 (BDA, m. 2006\82)}

La demandante (Borisova) recurre ante el TEDH, contra la República de Bulgaria, por una sentencia condenatoria dictada en un procedimiento entablado en su contra por una falta por hechos calificados de "alteración del orden público", los cuales fueron castigados con una "sanción administrativa" de cinco días de arresto. La sentencia es dictada por un tribunal de instancia sin posterior recurso en su contra, y, por lo tanto, la sentencia se ejecutó de inmediato.

El procedimiento de falta a que fue sometida la recurrente era simplificadísimo. En efecto, después de la detención policial de la señora Borisova, por desorden en la vía pública y agresión física leve a un policía, fue llevada a una comisaría, donde no contó con ninguna asistencia letrada. Tras lo cual, al cabo de aproximadamente dos horas, era conducida al tribunal para la celebración de la vista del juicio oral. Momentos antes del inicio de la vista se le presentó un acta de calificación que firmó sin hacerle objeción alguna. En el juicio sólo se practicó prueba de cargo y la acusada no tuvo oportunidad de proponer y practicar a su turno prueba de descargo, aun cuando en el juicio manifestó que no era consciente de la calificación, alegando tener testigos para refutar la imputación, la cual, afirma, sólo ha conocido en la misma vista del juicio con la lectura en voz alta que ha realizado el tribunal.

La demandante alega la violación de dos apartados del art. 6 (6.1 y 6.3) CEDH, concretamente aduciendo, entre otras cuestiones, la parcialidad del tribunal; no haber sido informada de la acusación y de la naturaleza y la causa de la acusación en forma oportuna; no haber dispuesto de tiempo y facilidades necesarias para preparar su defensa; no haber contado con defensor de su elección, y no haber tenido el derecho a practicar prueba en el juicio.

El TEDH considera en primer lugar que la naturaleza del asunto no es administrativo (sanción administrativa) sino penal, fundamentalmente por el carácter de privativa de libertad de la sanción impuesta, y, por lo tanto, sostiene que el procedimiento se refería a una "acusación penal”. Con ello hará aplicable al asunto las garantías procesales penales.

En virtud de las consideraciones precedentes es que estima violado los dos números del art. 6 alegados (6.1 y 6.3) del CEDH: el derecho a un juicio justo y el derecho de defensa.

su conjunto (...); y teniendo en cuenta la naturaleza del examen del caso que realizó el Tribunal Supremo (...); el Tribunal considera que cualquier defecto de procedimiento ante el Tribunal Regional fue subsanado ante el Tribunal Supremo".

"El Tribunal, por tanto, estima que los derechos del demandante a ser informado en detalle acerca de la naturaleza y los motivos de la acusación, y el derecho a disponer del tiempo y recursos suficientes para preparar su defensa, no fueron vulnerados". 
Específicamente y en primer lugar considera quebrantado el derecho a ser informado en el más breve plazo de la naturaleza y de la causa de la acusación formulada en contra de la recurrente y el derecho a preparar la defensa con tiempo y las facilidades necesarias. Se establece que no queda claro si realmente hubo información previa de la acusación, pero incluso de existir dicha información la circunstancia de haber contado con un tiempo escasísimo para preparar la defensa, hace infructuoso el mismo derecho a ser informado de la acusación, tanto como el derecho de defensa que se busca asegurar con aquél. La vinculación entre ambos es íntima: la infracción del primero supondrá necesariamente la infracción del segundo.

Con relación a lo anterior se halla además el otro motivo que se estima, cual es la violación del derecho a la prueba, ya que se establece que la recurrente no tuvo oportunidad de practicar prueba, aun cuando afirmó en la misma vista que tenía testigos para refutar la acusación.

Nos interesa esta sentencia en cuanto ratifica la vigencia y sentido del derecho a ser informado de la acusación respecto de su causa y naturaleza, de la necesidad de que esa información sea oportuna, valorándose aquello en relación con el aseguramiento de contar con tiempo y facilidades para preparar la defensa. De ahí que habrá de tenerse en cuenta las posibilidades que ofrece el proceso para formular alegaciones y practicar prueba sobre el contenido total e íntegro de la acusación, y diríamos más, la conexión con nuestro tema se produce cuando se advierte que esas conclusiones anotadas se han de proyectar sobre las posibles modificaciones que en el curso del proceso (juicio) se produzcan sobre el objeto del debate. Ampliada o modificada una acusación como consecuencia del resultado probatorio, modificada la defensa por la misma causa, estas situaciones nos pondrán ante la cuestión de preguntarnos por la aptitud del mecanismo (el que sea) para que se operen esos cambios, el cual debería garantizar el derecho de defensa y la oportunidad de prueba.

Una formulación progresiva y flexible de la acusación como acontece en los modelos europeos -italiano, alemán y español-, ${ }^{26}$ con las correspondientes posibilidades de ampliación del debate y nueva prueba, parece ser un imperativo que se adecua mejor a las exigencias de las garantías procesales como aparecen interpretadas por el TEDH. De esta manera, especial importancia puede tener al valorar las posibilidades de debate contradictorio y prueba en el caso de que el juez formule la tesis en la audiencia del juicio (art. 341

${ }^{26}$ En el Codice di procedura penale, art. 521. Vid. Nobili, M., La nuova procedura penale. Lezioni agli studenti, Clueb, Bologna, 1989, pp. 330-345; Fassone, E., Manuale pratico del nuovo processo penale (con Fortuna, Dragone, Giustozzi y Pignatelli), Cedam, terza edizione, Padova, 1993, pp. 845-847; Rafaraci, T., Le nuove contestazione nel processo penale, Giuffrè, Milano, 1996, pp. 33 y ss.; Cordero, F., Procedura penale, Giuffrè, Milano, 2001, cit., pp. 449-455; Calamandrei, I., "Diversità del fatto e modifica dell'imputazione nel Codice di Procedura penale del 1988”, en Rivista di Diritto e Procedura penale, 1996, pp. 643 y ss; Gianniti, P., "Rilievi sul 'fatto' nel processo penale”, en Rivista italiana de Diritto e Procedura penale, 1999, pp. 412 y ss; Giarda, A. y Spangher, G., Codice di procedura penale. Comentario, IPSOA, segunda edición, 2001, pp. 1463 y ss. En la StPO alemana se debe tener presente la correcta regulación de los parágrafos 264 y 265. Vid. Roxin, C., Derecho procesal penal, cit., pp. 160-161; Gómez Colomer, J. L., El proceso penal alemán..., cit., pp. 39-42 y 366-367. En la LECrime los arts. 650 y 732. Vid. Del Río Ferretti, C., La correlación..., cit., pp. 90 y ss. 
incisos $2^{\circ}$ y $3^{\circ} \mathrm{CPP}$ ), o las posibilidades de debate y prueba en el caso de que se introduzcan modificaciones a la acusación inicial en las conclusiones definitivas (art. 338 CPP).

\title{
III. CONCLUSIONES SOBRE LAS APORTACIONES DE
}

\author{
LA JURISPRUDENCIA DEL TEDH QUE PODRÍAN SER DE \\ UTILIDAD COMO CRITERIOS APLICABLES AL MODELO CHILENO
}

De manera general se puede afirmar que en la jurisprudencia del TEDH se observa un esfuerzo jurídico destinado a dotar de contenido a las cláusulas sobre el derecho al proceso justo (art. 6.1 CEDH) y del derecho a conocer la acusación (6.3 CEDH). Respecto a esta cuestión señala de manera clara que el derecho a conocer la acusación comprende no sólo los hechos sino también el derecho, de modo que la falta de conocimiento preciso de cualquier extremo del contenido jurídico de la acusación puede suponer una infracción de esta garantía. Otro aspecto que resulta interesante destacar es la relación que establece del derecho a conocer la acusación con el derecho a un juicio justo o equitativo, al sostener que el primero se incardina en el segundo. Con ello se dota de sustancia a una cláusula general a la que no es fácil atribuir un contenido normativo, lo cual conlleva en la práctica la ineficacia de la garantía.

En un plano más específico sobre concretas conclusiones sobre criterios deducidos de esta jurisprudencia y aplicables al caso chileno destacaremos las siguientes:

\section{Poder de calificación jurídica y modificación de bechos}

La jurisprudencia del TEDH también establece de manera reiterada que el juez penal tiene el poder de calificación jurídica y que por ello las calificaciones jurídicas realizadas por las partes no lo vinculan: puede entonces modificarlas, separándose de las realizadas por las partes.

Con todo, esa regla general conoce una importante limitación en los casos estudiados. En efecto, en varios de ellos (Colak, De Salvador Torres y Pélissier y Sassi) se declara que ese poder de calificación jurídica del juez penal no puede importar un medio para la modificación del sustrato fáctico de la acusación. Esta posición se refiere desde luego a supuestos de ampliación-agravación de la "imputación objetiva" o del contenido objetivo de la acusación, y no a la modificación que suponga disminución-atenuación de la misma.

Este es el criterio que se sienta especialmente en el caso de De Salvador Torres, con lo cual la doctrina del TEDH ratifica y adhiere al criterio de la homogeneidad delictiva desarrollado en el Derecho comparado. Se trata de un criterio normativo que tiene por objeto resolver los problemas que derivan de la modificación de la calificación jurídica con base en una modificación fáctica. ${ }^{27}$ Se pretende establecer una regla que comprenda

${ }^{27}$ Para un estudio extenso de esta cuestión vid. las proposiciones que se formulan en Del Río Ferretti, C., La correlación..., cit., passim. 
y regule el fenómeno -que hemos denominado, en otra parte, progresión-regresión delictiva- y discipline sus hipótesis admisibles.

Para tener una idea precisa de lo que es la homogeneidad delictiva con miras a proteger realmente el derecho de defensa y contradicción, habrá que atender no sólo al bien jurídico de los delitos, sino también y preferentemente a la estructura típica de ellos. Es decir, atender preferentemente a los elementos fáctico-jurídicos que tiene en cuenta la norma para configurar el tipo: ${ }^{28}$ se puede modificar la calificación jurídica, pasando de un hecho típico a otro distinto siempre que se trate de hechos delictivos homogéneos, esto es, con una estructura típica común. La homogeneidad delictiva admitida de forma incondicionada es la que se denomina homogeneidad descendente, ${ }^{29}$ la cual consiente la modificación de la calificación jurídica a causa de que el juez en su enjuiciamiento sustrae elementos fáctico-jurídicos que conformaban un tipo más elevado en la progresión delictiva. ${ }^{30}$ En este caso la prohibición de modificación de la imputación (acusación) no opera, ${ }^{31}$ pudiendo el juzgador calificar de forma distinta a la acusación siempre que lo haga por un tipo penal más simple o restringido, es decir, "degradado" o "reducido" respecto del de la acusación, ya que al ser el tipo por el que se condena un tipo "degradado" respecto del de la acusación, asegura que los elementos fácticos y jurídicos del tipo tenidos en cuenta en la calificación jurídica de la sentencia estaban contemplados en la figura más compleja y amplia de la acusación, respecto del cual el acusado se defendió, de modo que dicha defensa en todo caso alcance o cubra, como mínimo, todos los elementos necesarios para la subsunción regresiva de la sentencia.

Respecto a la hipótesis de la autoría y complicidad, el TEDH, en el caso Pélissier y Sassi, ha declarado expresamente que no es admisible el paso en sentencia desde autoría a complicidad (o viceversa), pues detrás de ese cambio de calificación se hallaría la modificación del hecho mismo de la acusación. El hecho de la autoría es completamente distinto del de la complicidad. Por ello se opone al cambio referido en sentencia. Con todo, no queda claro en la sentencia del TEDH si ello no sería admisible en términos absolutos o sólo se trata de una valoración del caso concreto atendiendo en realidad a la falta de oportuna notificación del cambio de participación y del debido debate.

Esta última cuestión tiene importancia pues conecta con una materia discutida sobre la identidad del hecho a efectos de individualización del objeto del proceso. La complicidad y también la inducción son formas de participación que presentan el pro-

${ }^{28}$ Vid. Antolisei, F., Manual de Derecho penal, Temis, Bogotá, 1988 (traducción de Guerrero, Jorge y Ayerra Redín, Marino), p. 126 y pp. 137-138. Este también es el criterio de la jurisprudencia española.

${ }^{29}$ Aclaramos que no descartamos la viabilidad de hipótesis de homogeneidad ascendente, aunque la cuestión requiere de matices teóricos y prácticos. Vid. Del Río Ferretti, C., La correlación..., cit., passim.

${ }^{30}$ Lo que la doctrina penal alemana denomina como la relación de subordinación entre tipos penales distintos. Vid. Gössel, K., Maurach, R. y Zipf, H., Derecho penal. Parte general, tomo II, Astrea, séptima edición alemana, Buenos Aires, 1995 (traducción Bofill Genszch) pp. 558-564.

${ }^{31}$ Nótese que en este punto la doctrina italiana moderna sostiene lo contrario, de modo que ni siquiera en este caso le está permitido al juez apartarse de oficio del hecho imputado por la acusación, y hacer una calificación degradada. Vid. Rafaraci, T., Le nuove..., cit., pp. 286-290. 
blema de que se basan en acciones distintas de las que despliega el autor (o coautor). ${ }^{32}$ En términos muy generales, el autor es el que realiza el hecho típico, mientras que el cómplice es el que coopera a la ejecución del hecho con actos anteriores o simultáneos. El inductor es tratado por la ley como autor, pero es evidente que material y sustantivamente no realiza el hecho típico, sino que su actuación, como su nombre lo indica, únicamente induce su ejecución.

Concretamente el Derecho chileno regula la inducción como una especie de autoría mediata, al contemplarla conjuntamente con las distintas formas de autoría en el art. 15 del CP, cuando en realidad es una especie de participación, como lo ha aclarado la doctrina $^{33}$. La complicidad está regulada en el art. 16 del CP, y no presenta problemas de interpretación, ya que está claro que son cómplices aquellos que cooperan a la ejecución del hecho por actos anteriores o simultáneos, siempre que no sea autor por no concurrir en él el dolo de ejecutar el hecho delictivo sino de auxiliar o colaborar.

En consecuencia, tanto en la complicidad como en la inducción sólo hay una contribución al hecho típico ajeno (el del autor), del cual se diferencia con claridad. Este es el motivo por el cual se debe descartar como criterio definidor del objeto normativo a la identidad del hecho (que en estas hipótesis ni siquiera es parcial).

La teoría normativa del hecho ha debido ser parcialmente modificada a raíz de la imposibilidad de apoyar la unidad del objeto procesal en la identidad normativa del hecho en las hipótesis de las formas de participación respecto del hecho de la autoría. La ineficacia de este criterio se explica porque las formas de participación suponen respecto de la autoría un hecho totalmente diverso en todos sus aspectos, de modo que mal podía intentarse hacer una justificación de la unidad del objeto del proceso desde esta perspectiva. En otras palabras, la identidad normativa del hecho es ineficaz para justificar la situación de que en la acusación se acuse a un sujeto como autor y se le acabe condenando por complicidad, o a la inversa. Son hechos radicalmente distintos. En consecuencia, si se mantenía la esencialidad de la conducta o actividad de ejecución típica como el criterio para discernir la unidad normativa del hecho y del objeto del proceso había que concluir que en la sentencia no se podía pasar a una forma de participación diversa sin romper dicha unidad, y, en consecuencia, sin infringir el deber de correlación objetiva.

Con todo, la doctrina proclive a posiciones normativas ha argumentado que en este caso no corresponde atender al hecho como forma de determinación de la unidad del objeto procesal, sino más bien al objeto material tutelado con la punición de las formas

${ }^{32}$ Vid. al respecto Del Río Ferretti, C., La correlación..., cit., passim.

${ }^{33}$ En doctrina está perfectamente claro que la inducción es una especie de participación distinta de la autoría mediata, vid. Cury Urzúa, E., Derecho penal. Parte general, tomo II, Editorial Jurídica de Chile, segunda edición, Santiago, 1992, pp. 241-242; Garrido Montt, M., Derecho penal. Parte general, tomo II, Editorial Jurídica de Chile, Santiago, 1994, pp. 308-312; Politoff Lifschitz, S., Matus Acuña, J. P. y Ramírez Guzmán, M., Lecciones de Derecho penal chileno. Parte general, Editorial Jurídica de Chile, segunda edición, Santiago, 2004, pp. 427-429. Parece sostener una cosa distinta Etcheberry Orthusteguy, A., Derecho penal. Parte general, tomo II, Editorial Jurídica de Chile, Santiago, 1998, pp. 90-94. 
de participación junto a la autoría. Es decir, al bien jurídicamente protegido, el cual sí es único en las formas de participación y la autoría. Sobre esta unidad (de bien jurídico) se sostendría la unidad de objeto procesal. Entonces se ha acudido a la regla del bien jurídico para salvar el problema que se presentaba para justificar el paso desde autoría en la acusación, a inducción o complicidad en la sentencia, o viceversa, en razón de que tanto la autoría como la inducción y complicidad, a pesar de sus diferencias fácticas de ejecución típica, suponen la infracción a una misma norma y bien jurídico, y por eso deben ser consideradas integrantes de un mismo objeto procesal. ${ }^{34}$ Lo que tienen de común todas las formas de participación es la afectación de un mismo bien jurídico y ello justifica que se juzguen como un objeto procesal único con la autoría.

Es evidente que el TEDH no llega a este tipo de consideraciones técnico-procesales, sino simplemente anota la conclusión de que autoría y complicidad se basan en hechos distintos, y que el cambio de calificación operado abruptamente sobre esa base produjo indefensión. Yace, sin embargo, en la Sentencia el problema de dilucidar qué hubiera resuelto el TEDH en caso de que efectivamente dicho cambio se hubiere introducido oportunamente, con el debido debate contradictorio. Parece en último término, según lo expresado antes, que el paso de autoría a complicidad u otra forma de participación en sentencia es más bien un problema de configuración flexible de acusación y debate contradictorio que de correlación, lo mismo se revela en los casos De Salvador Torres, Dallos y Borisova.

\section{La necesidad de configuración flexible de la acusación y debate contradictorio: conclusión válida para el sistema chileno. Insuficiencia del binomio de los artículos 259-341}

Del conjunto de la jurisprudencia analizada se desprende el establecimiento de una íntima relación entre defensa y debida contradicción con un modelo de configuración flexible y progresiva de la imputación, que permite su adaptación y ajuste hasta los momentos finales del juicio mismo, con el acompañamiento de las correspondientes oportunidades procesales de reacción para ampliar el objeto del debate.

Si se analizan con detenimiento los casos De Salvador Torres y Dallos, se observará que la desestimación de la demanda por parte del TEDH se basó en la existencia del oportuno ajuste de la acusación y de la correspondiente oportunidad de reacción procesal previa a la conclusión del juicio y decisión del juez penal. Por el contrario, cuando ha habido falta o ausencia de oportunidades defensivas (con contradicción y prueba) por

${ }^{34}$ Obsérvese que la participación respecto de la autoría supone la intervención de varios sujetos que realizan diversas acciones, pero todas dentro de una unidad delictiva. Rodríguez Devesa, J. M. y Serrano Gómez, A., Derecho penal español. Parte general, Dykinson, decimooctava edición, Madrid, 1995, pp. 806807, dicen: “Aunque haya varios partícipes, hay un solo delito...". Y más adelante añade: "La naturaleza accesoria de la participación es una necesidad conceptual. Participar es tomar parte en el acto de otro. La participación implica una conducta básica, la del autor, que realiza lo que Beling denominaba el núcleo del delito, y otra u otras conductas periféricas que acceden a la principal. El partícipe participa en el delito de otro, en la conducta del autor, que es el protagonista del delito; desempeña un papel secundario, visto desde la perspectiva de los actos de ejecución del núcleo del tipo”. 
no haberse modificado oportunamente la acusación el TEDH ha estimado las infracciones alegadas de los números 1 y 3 del art. 6 del CEDH, tal como aconteció en caso Pélissier y Sassi.

Para el modelo chileno adquiere gran relieve esta cuestión pues ello aparece como una de las cuestiones del diseño procesal mal resueltas. El CPP chileno no tuvo claridad sobre la importancia de esto, lo cual ha generado importantes problemas de interpretación jurisprudencial. 35,36

En los casos del Derecho italiano, alemán y español, ${ }^{37}$ en consonancia con la jurisprudencia del TEDH, se establece que el término de correlación (comparación) son las calificaciones definitivas o la imputación o acusación como se presenten después de la vista del juicio oral y una vez practicada la prueba, ya que tras el resultado probatorio puede haber necesidad de reformular parcialmente la acusación, de modo que sólo después de este momento se tiene la acusación definitivamente depurada y establecida. La sentencia debe guardar correlación con esta acusación.

El CPP dispone en cambio que la acusación se interponga, si es que hay mérito para ello, una vez concluida la etapa de investigación, con arreglo a lo dispuesto en el art. 259, dejando abierto un punto que a nuestro juicio trae un cierto grado de incertidumbre si no se intenta esclarecer. Nos referimos a la falta de previsión normativa expresa de una oportunidad posterior a la práctica de la prueba que tenga la finalidad de adecuar las conclusiones fácticas y jurídicas de la acusación inicial -art. 259-, ${ }^{38}$ ya que ésta se basa en puros antecedentes de la investigación: fuentes probatorias que todavía no han producido sus efectos jurídicos en el juicio, de modo que la acusación inicial es una acusación con base en conjeturas sobre lo que será la prueba. De ahí su radical provisionalidad. Analizadas las cosas desde esta perspectiva se muestra absurdo concluir que la falta de expresa regulación de un segundo acto acusatorio pueda implicar la intención del legislador de establecer un sistema de preclusión acusatoria rígido previo a la misma producción de prueba. Es decir, en palabras simples, que la acusación útil para el art. 341 sea la del art. 259.

La acusación inicial que se realiza en la etapa intermedia o de preparación del juicio oral debería ser entonces una acusación provisional en cuanto no puede recoger las modificaciones que probablemente sea menester realizar, considerando el resultado probatorio. Convendría contemplar expresamente la posibilidad de un segundo momento procesal para actualizar y ajustar la acusación al resultado probatorio o aprovechar el cauce del art. 338 CPP (alegatos de clausura).

35 Vid. infra.

${ }^{36}$ Los argumentos que siguen han sido expuestos previamente en Del Río Ferretti, C., "Deber de congruencia (rectius, correlación) de la sentencia penal y objeto del proceso: un problema insoluble para la jurisprudencia chilena", en Ius et Praxis, $\mathrm{N}^{\circ} 2,2008$, passim.

37 Vid. supra nota 26.

${ }^{38} \mathrm{La}$ acusación que nosotros denominamos inicial es la única acusación prevista explícitamente en el nuevo CPP, denominada "acusación” a secas. 
Esta cuestión es la que ha puesto a la jurisprudencia en un dilema que no ha sabido enfrentar. La causa está en la regulación normativa imperfecta y lagunar ${ }^{39}$ que ha dado lugar a la imprevisión normativa de la necesidad de actualizar la acusación en el curso del juicio oral, especialmente al resultado probatorio, y la necesidad correlativa de prever oportunidades procesales finales para la ampliación del debate y de prueba nueva. Dicha imprevisión que implicaba (e implica, según se interprete) una fuerte preclusión acusatoria ex ante, previa a la práctica de la prueba, la jurisprudencia ha decidido resolverla, en momentos distintos, de dos formas, cada cual insatisfactorias. La primera de ellas consiste en entender que el deber de correlación se encuentra tan estrictamente formulado que cualquiera modificación introducida en la sentencia, por insignificante que ella sea, lesiona el deber de correlación de ésta con la acusación inicial, lo cual no sería sino una (mala) forma de resolver el problema de la imposibilidad de ajustar la acusación al resultado probatorio, pues sólo de esa manera la preclusión acusatoria sería capaz de obrar como límite eficaz, delimitador eficaz de los poderes de resolución jurisdiccional: de lo contrario, el juez de forma repentina introduciría en el último momento modificaciones fácticas no asumidas e introducidas por la acusación, que podrían alterar el objeto del proceso o, sin alterarlo, podrían provocar lesiones al derecho de defensa por modificaciones al objeto del debate, como es el caso de la introducción de hechos accidentales. Esta ha sido la alternativa o solución que inicialmente parecía imponerse en buena parte de la doctrina jurisprudencial sin muchos matices. ${ }^{40}$ Se tendía a considerar de manera extrema la correlación, sobre la base de una preclusión rígida en la formulación de la acusación, lo cual importaba la total inmodificabilidad (inmutabilidad) de los hechos de la acusación inicial. Ésta quedaba rígidamente definida antes del juicio y esa delimitación operaba en forma absoluta. O en otras palabras, la radical aplicación de la preclusión acusatoria tenía que ser acompañada de una concepción extrema de correlación, ya que de lo contrario la garantía limitadora e informadora de la acusación se esfumaba.

Con esta solución se produjeron fallos aberrantes: se dictaron sentencias de absolución por modificaciones en la ubicación temporal del hecho (error en una fecha) o de un dato espacial (cambios del lugar de acaecimiento), o por la modificación de la modalidad concreta de comisión, elementos fácticos claramente irrelevantes desde el punto de vista

39 Este tema lo hemos estudiado previamente en "Deber de congruencia (rectius, correlación) de la sentencia penal y objeto del proceso: un problema no resuelto en la ley e insoluble para la jurisprudencia chilena", en Ius et Praxis, 14.2, 2008, pp. 100 y ss., aunque desde el punto de vista del objeto del proceso.

${ }^{40}$ Vid. sólo a modo de ejemplo de esta línea jurisprudencial las siguientes sentencias: SCA de La Serena de 11 de diciembre de 2001, rol corte n. 133; SCA de La Serena de 8 de abril de 2005, rol corte n. 57; SCA de La Serena de 30 de marzo de 2005, rol corte n. 50; SCA de San Miguel de 11 de agosto de 2008, rol corte n. 904-2008, y Sentencia de TJO de Santiago $\left(1^{\circ}\right)$ de 4 de abril de 2006, rit 15-2006.

Así en las sentencias indicadas se ha considerado infringido el deber de correlación porque se ha modificado el relato específico de la modalidad comisiva de un robo con intimidación o de un robo con violencia, o porque se ha modificado en sentencia el lugar físico donde han sucedido los accesos carnales de una violación o la ubicación temporal de estos, o porque se ha modificado el relato y la ubicación temporal de un tráfico de estupefacientes. 
del objeto del proceso. ${ }^{41}$ Bien es verdad, eso sí, que en casos concretos una circunstancia histórico-natural puede tener relevancia ya no por su trascendencia para el objeto del proceso, sino en función del derecho de defensa, pero ello podría haber sido resuelto justamente a través de la técnica de configuración flexible y progresiva de la acusación con posibilidades de ampliación del debate y prueba durante el desarrollo del proceso (juicio oral), vía que no parece todavía vislumbrada por la jurisprudencia.

La otra forma de enfrentar el problema (insatisfactoria así mismo) es aquella que tiende a imponerse en la más reciente jurisprudencia. ${ }^{42}$ En ella también se parte de la preclusión estricta del acto de acusación del art. 259 CPP, pero frente a esa preclusión producida antes de la práctica de la prueba no se está dispuesto a dejar limitado de manera extrema al juez, al punto de llegar a las situaciones de pronunciar absoluciones por cambios de lugar, de tiempo o de modalidad comisiva, con todas las consecuencias que ello conlleva. Para ello se ha acudido a una concepción normativa simplificada (e imprecisa) sobre el hecho: se esgrime la teoría normativa del hecho -sin mucha claridad-a efectos de correlación. Se afirma, de este modo, que el juez se halla limitado por el hecho procesalmente relevante definido por el núcleo esencial del mismo (aunque nunca se diga cuál es ese núcleo), pero no por esos fragmentos o circunstancias fácticos accesorios jurídicamente irrelevantes (rectius, accidentales). Con esa afirmación general e imprecisa la jurisprudencia suele resolver sin más la cuestión, llegando a la conclusión de que los hechos o circunstancias accidentales pueden ser introducidos o modificados por el juez en la sentencia.

${ }^{41}$ Vid. nota 40.

${ }^{42}$ Esta corriente jurisprudencial se expresa, entre muchas, en las siguientes sentencias: las primeras son del TJO de Antofagasta (redactor Dinko Franulic), así en Sentencia de 20 de mayo de 2003, rol interno 30-2003; Sentencia de 10 de agosto de 2003, rol interno 70-2003, y Sentencia de 17 de septiembre de 2004, rol interno 93-2004. Así mismo la STJO de Rancagua, de 18 de noviembre de 2004, rol interno 672004, BDLN; STJO de Rancagua, de 18 de junio de 2005, rol interno 60-2005, BDLN; STJO de Iquique, de 10 de febrero de 2005, rol interno 293-2004, BDLN, y STJO de Arica, de 20 de septiembre de 2005, rol interno 53-2005, BDLN; STJO de Santiago $\left(7^{\circ}\right)$, de 18 de enero de 2006, rol interno 3-2005, BDLN; STJO de Curicó ( $2^{a}$ sala), de 10 de junio de 2008, rol interno 14-2008, BDLP.

También SCA de Copiapó, de 23 de abril de 2004, rol 2-2004, que acierta al rechazar que modificaciones accesorias puedan suponer la infracción del deber de correlación; y SCA de Copiapó, de 24 de septiembre de 2007, rol 128-2007, BDLN. En el mismo sentido la SCA de Temuco, de 13 de octubre de 2003, rol 3232003; SCA de Santiago, de 29 de marzo de 2006, rol 232-2006, BDLN, y SCA de Santiago, de 3 de agosto de 2007, rol 1121-2007, BDLN; SCA de Rancagua, de 1 de agosto de 2008, rol 249-2008, BDLP; SCA de Arica, de 4 de agosto de 2008, rol 63-2008, BDLP. E incluso la misma Corte de Apelaciones de La Serena, en Sentencia de 07 de marzo de 2008, rol 19-2008, BDLP, aunque en una sentencia del último tiempo vuelve a incurrir en el mismo error que se critica: SCA de La Serena, de 18 de febrero de 2008, rol 332-2007.

En la línea normativa del hecho así mismo hay jurisprudencia de la Corte de Apelaciones de Concepción que ha resuelto en determinados casos con acierto, pero sin proceder bajo criterios estrictamente técnicos para el hecho procesal y su eventual alteración. Vid. al respecto a Cortez Matcovich, Gonzalo, El recurso de nulidad..., cit., pp. 274 y ss. Últimamente puede consultarse SCA de Concepción, de 24 de septiembre de 2007, rol 416-2007, BDLN; SCA de Concepción, de 6 de diciembre de 2007, rol 586-2007, BDLN; SCA de Concepción, de 14 de diciembre de 2007, rol 601-2007, BDLN. 
La solución a la que se llega con este criterio puede ser parcialmente correcta respecto al deber de correlación, pero olvida por completo que hechos accidentales y, por lo tanto, irrelevantes a efectos de objeto del proceso pueden tener importancia jurídico-penal ${ }^{43}$ o, sin ella, pueden ser importantes a efectos de la determinación del objeto del debate y de la eficacia del derecho de defensa. La introducción tardía en la sentencia definitiva privaría a la defensa de ampliar su defensa a los nuevos términos del objeto del debate con necesidad incluso de nueva prueba. Lo que se apunta puede verse, entre otras, en la SCS de 24 de diciembre de 2007, rol 5415-2007, en la cual se afirma que en un delito de parricidio frustrado por envenenamiento son completamente irrelevantes la determinación del fármaco y de la dosis suministrada, de modo que el establecimiento en sentencia definitiva de estos elementos fácticos accesorios no constituye infracción al deber de congruencia. Con esto la sentencia justamente elude los problemas vinculados, ya no a la correlación, sino al objeto del debate y al derecho de defensa en juicio oral, pues resulta más que evidente que el conocimiento del fármaco y de la forma precisa de suministro y dosis en un envenenamiento resultan o pueden resultar datos fácticos relevantes con relación al objeto del debate. Es evidente que desde el punto de vista del objeto del debate y del derecho de defensa, en un delito de parricidio por envenenamiento, sí que importa el tipo de fármaco y la dosis utilizada para ocasionar la muerte.

Con la explicación precedente se ha querido demostrar que la forma de resolver el problema expuesto es estableciendo un sistema progresivo y flexible de acusación, que permita actualizarla a los resultados probatorios del juicio: en último término la acusación en su formulación final debería asumir las modificaciones fácticas, siempre en el entendido de la inalteración del objeto del proceso, salvo excepciones. Ello impone la necesidad de interpretación normativa adecuada que entienda que al cabo de la práctica de la prueba los acusadores podrán formular una acusación definitiva aprovechando la oportunidad de los alegatos finales (art. $338 \mathrm{CPP}$ ), en la que se permita introducir modificaciones al relato fáctico y a las calificaciones jurídicas contenidas en él. La misma oportunidad habría que concederle a la defensa. Con ello se abriría camino a un mecanismo de ampliación del objeto del debate por el cual las partes puedan formular de forma definitiva sus alegaciones y peticiones fundamentales, tras la práctica de la prueba del juicio oral.

Pero así mismo, si se admite una modificación de la acusación y defensa tras la prueba, con el resultado de la ampliación del objeto del debate, habría necesidad de permitir ampliación del debate contradictorio con hipótesis de nueva prueba, al menos por una vez. Parece una consecuencia normativa imprescindible si se modifica el objeto del debate porque surge algún hecho o aspecto fáctico desconocido (no alegado).

43 En la misma línea jurisprudencial criticada pueden consignarse la STJO de Cauquenes, de 9 de noviembre de 2005, rol 22-2005, en la que se descarta de plano la relevancia de las modificaciones del hecho en su ubicación o determinación temporal, y la STJO de San Felipe, de 6 de febrero de 2008, rol interno 63-2007, en la cual, a su turno, se desestima la importancia de la determinación espacial del hecho sin mayores motivaciones al respecto. 


\section{BiBLIOGRAFÍA}

Aguilera de Paz, E., Comentarios a la Ley de Enjuiciamiento Criminal, tomo V, Hijos de Reus, Madrid, 1914.

Aguilera de Paz, E., Comentarios a la Ley de Enjuiciamiento Criminal, tomo VI, Hijos de Reus, Madrid, 1914.

Antolisei, F., Manual de Derecho penal, Temis, Bogotá, 1988 (traducción de Guerrero, Jorge y Ayerra Redín, Marino).

Calamandrei, I., "Diversità del fatto e modifica dell'imputazione nel Codice di Procedura penale del 1988", en Rivista di Diritto e Procedura penale, 1996.

Cordero, F., Procedura penale, Giuffrè, Milano, 2001.

Cortez Matcovich, G., El recurso de nulidad. Doctrina y jurisprudencia, LexisNexis, segunda edición, Santiago, 2006.

Cury Urzúa, E., Derecho penal. Parte general, tomo II, Editorial Jurídica de Chile, segunda edición, Santiago, 1992.

De la Oliva Santos, A., Derecho procesal penal (con Aragoneses Martínez, Hinojosa Segovia, Muerza Esparza y Tomé García), ECERA, cuarta edición, Madrid, 1999.

Del Río Ferretti, C., La correlación de la sentencia con la acusación y la defensa. Estudio comparado del Derecho español con el chileno, Universidad de Valencia (Servicio de publicaciones), versión cederrón, 2007.

- $\quad$ "Deber de congruencia (rectius, correlación) de la sentencia penal y objeto del proceso: un problema no resuelto en la ley e insoluble para la jurisprudencia chilena", en Ius et Praxis, 14.2, 2008.

Etcheberry Orthusteguy, A., Derecho penal. Parte general, tomo II, Editorial Jurídica de Chile, Santiago, 1998.

Fassone, E., Manuale pratico del nuovo processo penale (con Fortuna, Dragone, Giustozzi y Pignatelli), Cedam, terza edizione, Padova, 1993.

Ferrajoli, L., Principia iuris. Teoria del diritto e della democrazia, vol. I, Laterza, Bari, 2007.

Garrido Montt, M., Derecho penal. Parte general, tomo II, Editorial Jurídica de Chile, Santiago, 1994.

Gianniti, P., "Rilievi sul 'fatto' nel processo penale”, en Rivista Italiana de Diritto e Procedura Penale, Giuffrè, Milano, 1999.

Giarda, A. y Spangher, G., Codice di procedura penale. Comentario, IPSOA, segunda edición, 2001.

Goldschmidt, J., Problemas jurídicos y políticos del proceso penal, Bosch, Barcelona, 1935.

Gómez Colomer, J. L., El proceso penal alemán. Introducción y normas básicas, Bosch, Barcelona, 1985.

Gössel, K., Maurach, R. y Zipf, H., Derecho penal. Parte general, tomo II, Astrea, séptima edición alemana, Buenos Aires, 1995 (traducción Bofill Genszch).

Matus Acuña, J. P., Ramírez Guzmán, M. y Politoff Lifschitz, S., Lecciones de Derecho penal chileno. Parte general, Editorial Jurídica de Chile, segunda edición, Santiago, 2004.

Montero Aroca, J., Principios del proceso penal, Tirant lo Blanch, Valencia, 1997.

NoBiLI, M., La nuova procedura penale. Lezioni agli studenti, Clueb, Bologna, 1989.

Ortells Ramos, M., "Principio acusatorio, poderes oficiales del juzgador y principio de contradicción. Una crítica del cambio jurisprudencial sobre correlación entre acusación y sentencia”, en Justicia, IV, 1991.

Ossandón Widow, M. y Rodríguez Collao, L., Delitos contra la función pública. El Derecho penal frente a la corrupción política, administrativa y judicial, Editorial Jurídica de Chile, Santiago, 2005. 
Rafaraci, T., Le nuove contestazione nel processo penale, Giuffrè, Milano, 1996.

Rodríguez Devesa, J. M. y Serrano Gómez, A., Derecho penal español. Parte general, Dykinson, décimo octava edición, Madrid, 1995.

Roxin, C., Derecho procesal penal, Editores del Puerto, Buenos Aires, 2000 (traducción de Córdoba y Pastor).

Spangher, G. y Giarda, A., Codice di procedura penale. Comentario, IPSOA, segunda edición, 2001.

TAruffo, M., Precedente e giurisprudenza, Editoriale Scientifica, 2007.

\section{Jurisprudencia ANALIZAda}

\section{JURISPRUDENCIA TEDH}

Caso Delcourt. STEDH de 17 de enero de 1970.

Caso Colak. STEDH de 6 de diciembre de 1988 (Núm. 0180/1988). Base de datos El Derecho 1988/10492.

Caso Gea Catalán. STEDH de 10 de febrero de 1995 (BDA, m. TEDH 1995\1).

Caso De Salvador Torres. STEDH de 24 de octubre de 1996 (BDA, m. TEDH 1996\1).

Caso Pélissier y Sassi. STEDH de 25 de marzo de 1999 (BDA, m. TEDH 1999\10).

Caso Dallos. STEDH de 1 de marzo de 2001 (BDA, m. TEDH 2001\197).

Caso Borisova. STEDH de 21 de diciembre de 2006 (BDA, m. TEDH 2006\82).

\section{JURISPRUdENCIA CHILENA}

\section{A. Corte Suprema}

SCS de 24 de diciembre de 2007, rol 5415-2007.

B. Cortes de Apelaciones

SCA de La Serena, de 11 de diciembre de 2001, rol corte n. 133.

SCA de Temuco, de 13 de octubre de 2003, rol 323-2003.

SCA de Copiapó, de 23 de abril de 2004, rol 2-2004.

SCA de La Serena, de 30 de marzo de 2005, rol corte n. 50.

SCA de La Serena, de 8 de abril de 2005, rol corte n. 57.

SCA de Santiago, de 29 de marzo de 2006, rol 232-2006, BDLN.

SCA de Santiago, de 3 de agosto de 2007, rol 1121-2007, BDLN.

SCA de Copiapó, de 24 de septiembre de 2007, rol 128-2007, BDLN.

SCA de Concepción, de 24 de septiembre de 2007, rol 416-2007, BDLN.

SCA de Concepción, de 6 de diciembre de 2007, rol 586-2007, BDLN.

SCA de Concepción, de 14 de diciembre de 2007, rol 601-2007, BDLN.

SCA de La Serena, de 18 de febrero de 2008, rol 332-2007.

SCA de La Serena, de 07 de marzo de 2008, rol 19-2008, BDLP.

SCA de Rancagua, de 1 de agosto de 2008, rol 249-2008, BDLP.

SCA de Arica, de 4 de agosto de 2008, rol 63-2008, BDLP.

SCA de San Miguel, de 11 de agosto de 2008, rol corte n. 904-2008, BDLP.

B. Tribunales de Juicio Oral 
STJO de Antofagasta, de 20 de mayo de 2003, rol interno 30-2003.

STJO de Antofagasta, de 10 de agosto de 2003, rol interno 70-2003.

STJO de Antofagasta, de 17 de septiembre de 2004, rol interno 93-2004.

STJO de Cauquenes, de 9 de noviembre de 2005, rol interno 22-2005, BDLN.

STJO de Rancagua, de 18 de noviembre de 2004, rol interno 67-2004, BDLN.

STJO de Iquique, de 10 de febrero de 2005, rol interno 293-2004, BDLN.

STJO de Rancagua, de 18 de junio de 2005, rol interno 60-2005, BDLN.

STJO de Arica, de 20 de septiembre de 2005, rol interno 53-2005, BDLN.

STJO de Santiago $\left(7^{\circ}\right)$, de 18 de enero de 2006, rol interno 3-2005, BDLN

STJO de Santiago $\left(1^{\circ}\right)$, de 4 de abril de 2006, rit 15-2006.

STJO de San Felipe, de 6 de febrero de 2008, rol interno 63-2007.

STJO de Curicó ( $2^{\mathrm{a}}$ sala), de 10 de junio de 2008, rol interno 14-2008, BDLP. 